\title{
Aerological observations in the Tropics in the Early Twentieth Century
}

\author{
STEFAN BRÖNNIMANN* and ALEXANDER STICKLER
}

Oeschger Centre for Climate Change Research and Institute of Geography, University of Bern, Switzerland

(Manuscript received December 10, 2012; in revised form April 10, 2013; accepted April 10, 2013)

\begin{abstract}
In the first decades of the $20^{\text {th }}$ century, aerological observations were for the first time performed in tropical regions. One of the most prominent endeavours in this respect was ARTHUR BERSON's aerological expedition to East Africa. Although the main target was the East African monsoon circulation, the expedition provided also other insights that profoundly changed meteorology and climatology. BERSON observed that the tropical tropopause was much higher and colder than that over midlatitudes. Moreover, westerly winds were observed in the lower stratosphere, apparently contradicting the high-altitude equatorial easterly winds that were known since the Krakatoa eruption ("Krakatoa easterlies"). The puzzle was only resolved five decades later with the discovery of the Quasi-Biennial Oscillation (QBO). In this paper we briefly summarize the expedition of BERSON and review the results in a historical context and in the light of the current research. In the second part of the paper we re-visit BERSON's early aerological observations, which we have digitized. We compare the observed wind profiles with corresponding profiles extracted from the "Twentieth Century Reanalysis", which provides global three-dimensional weather information back to 1871 based on an assimilation of sea-level and surface pressure data. The comparison shows a good agreement at the coast but less good agreement further inland, at the shore of Lake Victoria, where the circulation is more complex. These results demonstrate that BERSON's observations are still valuable today as input to current reanalysis systems or for their validation.
\end{abstract}

Keywords: Historical aerology, Berson westerlies, Quasi-Biennial Oscillation, tropical tropopause.

\section{Introduction}

Imagine tropical meteorology around 1900. The tropics were of vital interest for the colonial powers and a large population lived in the tropics. Monsoon failures (including the droughts of 1877-1878) and tropical cyclones in the second half of the $19^{\text {th }}$ century had demonstrated how strongly societies and economies in the tropics depend on weather and how devastating a failure of monsoon rain can be. Various organizations and meteorological offices began measuring programs in the late $19^{\text {th }}$ century with the aim of better understanding interannual variations of climate (both in the tropics and extratropics) and its relation to the tropical circulation (e.g., SHAW, 1905; DE ORY and Palomares, 2005). However, apart from its use for navigational purposes not much was known on monsoon circulations. Specifically, aerological observations were missing to determine the upper-level flow. With his aerological expedition to East Africa in 1908, ARTHUR BERSON aimed at filling this gap.

In this paper, which accompanies the edited translation of a paper by SÜRING (1910) on BERSON's expedition, we revisit tropical aerology of that time in general and BERSON's expedition in particular from a present day perspective. BERSON's work was influential to the present day

\footnotetext{
*Corresponding author: Stefan Brönnimann, Oeschger Centre for Climate Change Research and Institute of Geography, University of Bern, Hallerstrasse 12, 3012 Bern, Switzerland,

e-mail: stefan.broennimann@giub.unibe.ch
}

- not because of the monsoon circulation, but because of the observation of the tropical tropopause and of westerly winds in the equatorial lower stratosphere.

We have digitized the aerological observations of BERSON, together with most other aerological observations of that time. Given the current emphasis of developing global historical weather data sets, these observations can provide important information even today. We compare the observations with the "Twentieth Century Reanalysis", which provides global three-dimensional weather information back to 1871 based on surface and sea-level pressure.

The paper is organized as follows. Section 2 provides an introduction into the state of tropical meteorology and aerology around 1900. In Section 3 we give short biographies of ARTHUR BERSON and REINHARD SÜRING and describe the East Africa Expedition. In Section 4 we put BERSON's results on the tropical tropopause and the lower stratospheric easterlies into context. We then present, in Section 5, the digitized aerological observations from this expedition and compare them with the "Twentieth Century Reanalysis" (20CR, COMPO et al., 2011). Conclusions are drawn in Section 6.

\section{Tropical meteorology and aerology around 1900}

Very little was known about the three-dimensional monsoon circulation around 1900. While the trade winds at the surface had been studied for a long time 


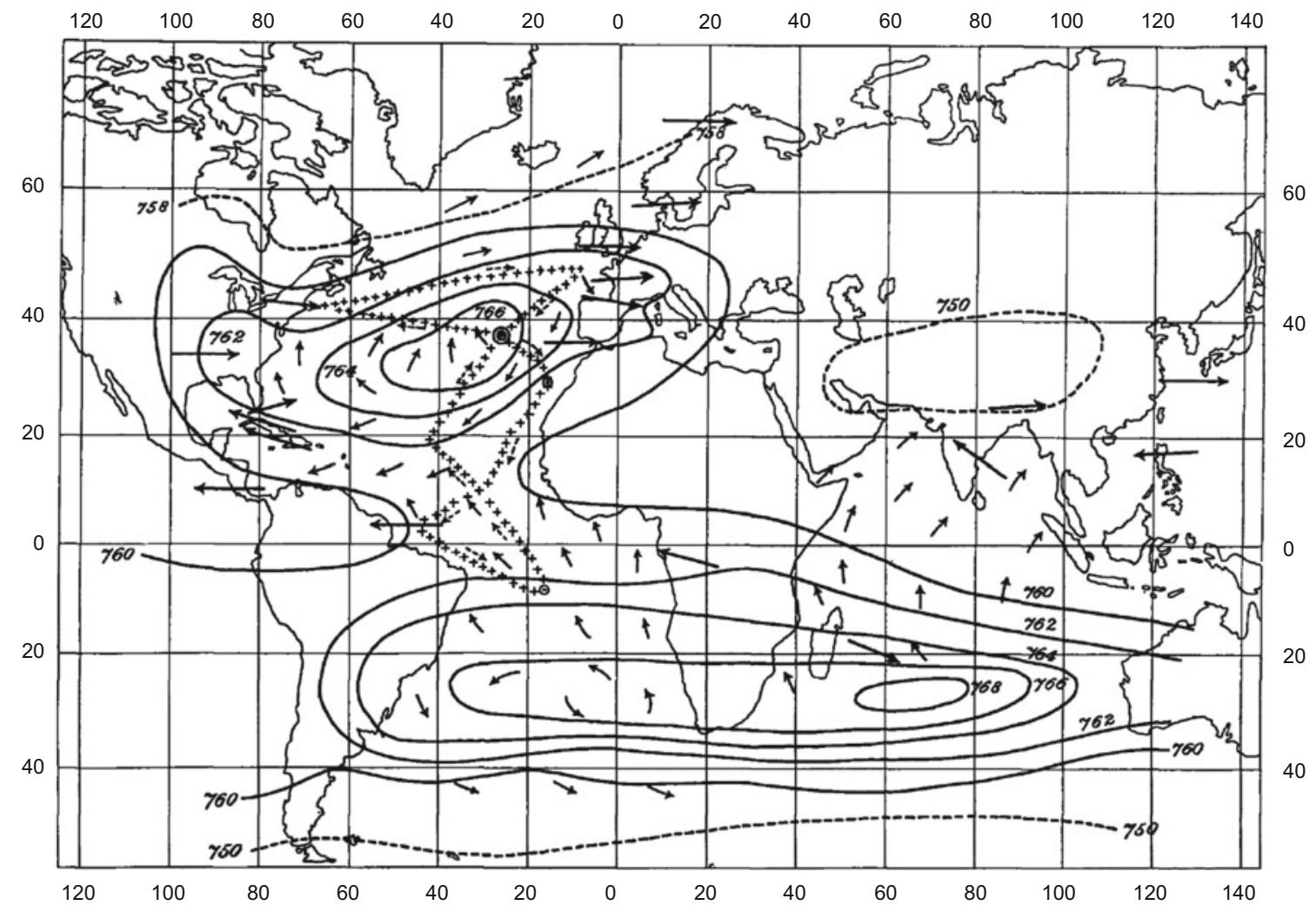

Figure 1: Isobars and winds for July (from RотCH, 1902). Short arrows (surface winds) and isobars are taken from the Meteorological Atlas of HANN (1887). Long arrows indicate cirrus motion.

(HALLEY, 1686; HADLEY, 1735) and attempts had been made to derive general conclusions on the zonal mean atmospheric circulation (FERREL, 1856; see also GRAMELSBERGER, 2009), the upper-level flow was basically unknown. One reason for this was the general lack of upper-air information from the tropics and subtropics, which at that time was limited to few high-elevation sites and observations of cirrus movement or the spreading of volcanic ash clouds.

Figure 1 (from RoTCH, 1902) summarizes the state of the knowledge. Isobars and short arrows (based on the Atlas of Meteorology, HANN, 1887) show the surface pressure and trade winds, respectively, while the long arrows indicate cirrus cloud motion. Some of the cloud observations as well as observations from Tenerife suggested an antitrade wind at upper levels, but observational evidence was very limited.

Aerological observations had only recently been developed and brought to operational standards. At the beginning stood manned balloon flights starting in Germany in 1888, undertaken by the so-called Luftschifferbataillon. The first meteorological kite flights had been undertaken by EDY 1891 and ROTCH 1894 in the USA. The first ballon-sondes had been launched in 1892 by the French HERMITE and BESANÇON. They were a more independent means of obtaining vertical soundings and soon reached 20,000 m altitude (PRINCE ALBERT OF MONACO, 1907). But even in Europe and
North America, aerological observations were still in the fledgling stages, with just very few sites such as the Blue Hill Observatory (south of Boston), the Trappes observatory close to Versailles or the Aeronautical Observatory in Tegel and later on Lindenberg (southeast of Berlin) at which observations were done on a regular basis. Aerologists were organized in the International Aeronautical Association (see also STEINHAGEN, 2009a). Aerological observations seemed promising for furthering the understanding of monsoons and tropical circulation. Around 1900, many of the leading aerologists (among them ABBOTT LAWRENCE ROTCH, Director of the Blue Hill observatory and one of the main developers of the meteorological kite, HUGO HERGESELL, Director of the Aerological Observatory in Strasbourg and head of International Aeronautical Association, ARTHUR BERSON, and LÉON-PHILIPPE TEISSERENC DE BORT) had plans for aerological observations in the tropics and presented them to the International Aeronautical Association and to the meteorological community.

Soon, various activities started. HUGO HERGESELL and PRINCE ALBERT OF MONACO made aerological observations onboard the "Princess Alice" at Tenerife in 1904 and 1905 (STEINHAGEN, 2009a). LÉON-PHILIPPE TEISSERENC DE BORT and LAWRENCE ROTCH made aerological observations 1905 in Tenerife and 1906 in the surrounding waters (DE ORY and PALOMARES, 2005). In 1906/1907, the "MS Planet" cruised from Europe 

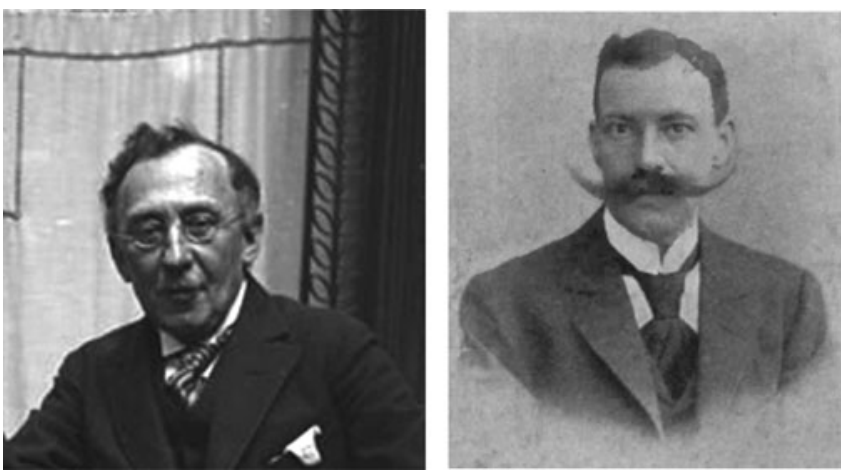

Figure 2: Photographs of ARTHUR BERSON in 1929 (left, Bundesarchiv Bild 102-08272) and of REINHARD SÜRING (right, source: HILDEBRANDT, 1907).

around Africa and the Indian Ocean to the Philippines, making aerological observations with kites and registering balloons (BRÖNNIMANN et al., 2011). In 1908 ARTHUR BERSON started his aerological expedition to East Africa and in 1909, the Dutch, equipped and supported by ASSMANN, started aerological observations in Batavia (VAN BEMMELEN, 1911).

The results of these undertakings, specifically those of BERSON's expedition, were very fruitful and profoundly changed climatology. The first World War put an end to a further extension of these activities. Although aerological measurements were performed in the tropics in the 1920s and 1930s, the modern era of tropical meteorology started only after the Second World War (RIEHL, 1954).

\section{BERSON, SÜRING, and the East Africa expedition of 1908}

\subsection{ARTHUR BERSON}

ARTHUR BERSON (Fig. 2) was born on 6 August 1859 in Neu Sandez, Galicia (now Nowy Sącz, Poland). He first studied and taught languages, when in 1887 he began studies in Geology (with FERDINAND VON RICHTHOFEN) and Meteorology (WILHELM VON BEZOLD) in Berlin (see SteINHAGEN, 2009b, for the following). His main interest was atmospheric physics. In 1890 BERSON became assistant of RICHARD ASSMANN (see EMEIS, 2012) at the Aeronautical Observatory of Berlin-Tegel, where he was engaged in manned balloon observations. In fact, he participated in 50 out of the 65 balloon cruises within the "Berliner wissenschaftliche Luftfahrten" (BERNHARDT, 2000). The results were published by ASSMANN, BERSON and GROSS (ASSMANN and BERSON, 1899, 1900a,b). These cruises established the vertical temperature structure over Europe in the lower to middle troposphere. BERSON continued manned balloon flights over Europe, but already had plans for an expedition to other regions of the globe.
On 31 July 1901, BERSON and SÜRING set a height record for manned balloon flights. In an open gondola they ascended to ca. $10,800 \mathrm{~m}$, where they managed to open a valve before becoming unconscious. Both survived the flight. Apart from setting a new record, the measurements obtained during the flight confirmed the observations of a parallel ascent of a registering balloon. This fact was important for establishing the reliability of the measurements and opened the door to the discovery of the stratosphere in 1902 by RICHARD ASSMANN and LÉON-PHILIPPE TEISSERENC DE BORT (ASSMANN, 1902; ASSMANN and BERSON, 1902; TEISSERENC DE BORT, 1902).

In 1905 BERSON moved to the newly founded Aeronautical Observatory of Lindenberg. In that position, BERSON finally conducted his East African expedition. In 1910, a year after the return from Africa, BERSON left Lindenberg to become director of the Department for Meteorological and Aeronautical Instruments at the Optische Anstalt C.P. Görz. He planned a second expedition to the tropics, however, only a preparatory expedition could be performed due to the outbreak of the World War. BERSON then worked for Junkers and was engaged in Arctic aerology. BERSON died in 1942 (SÜRING, 1943).

\subsection{REINHARD SÜRING}

REINHARD SÜRING (Fig. 2, right) was born on 15 May 1866 in Hamburg. He studied mathematics and natural sciences and then became assistant at the Prussian Meteorological Institute in 1890 and later at the Meteorologisch-Magnetisches Observatorium in Potsdam. He participated in numerous scientific balloon flights, including the record-breaking flight with BERSON in 1901. He became department head and after 1928 director of the Meteorologisch-Magnetisches Observatorium in Potsdam. SÜRING is also known for his famous textbook, co-authored with JULIUS HANN, on meteorology (HANN and SÜRING, 1915). SÜRING also was co-editor of the Meteorologische Zeitschrift - at first together with JULIUS HANN - from 1908 to 1944 and from 1946 to 1950 editor of the successor journal Zeitschrift für Meteorologie (see EMEIS, 2008).

\subsection{BERSON's East Africa expedition}

Since the late $1890 \mathrm{~s}$, BERSON was planning aerological expeditions to other regions of the globe (see STEINHAGEN, 2009b, and SÜRING, 1910, for the following). He laid out his plans to ASSMANN already in 1900, but funding could not be assured, while at the same time other aerologists had already started to make measurements in tropical regions. The ambitious plan had to be downsized and was delayed several times. BERSON focused on tropical continents and monsoon circulations, which, as he felt, were not covered well enough by the 


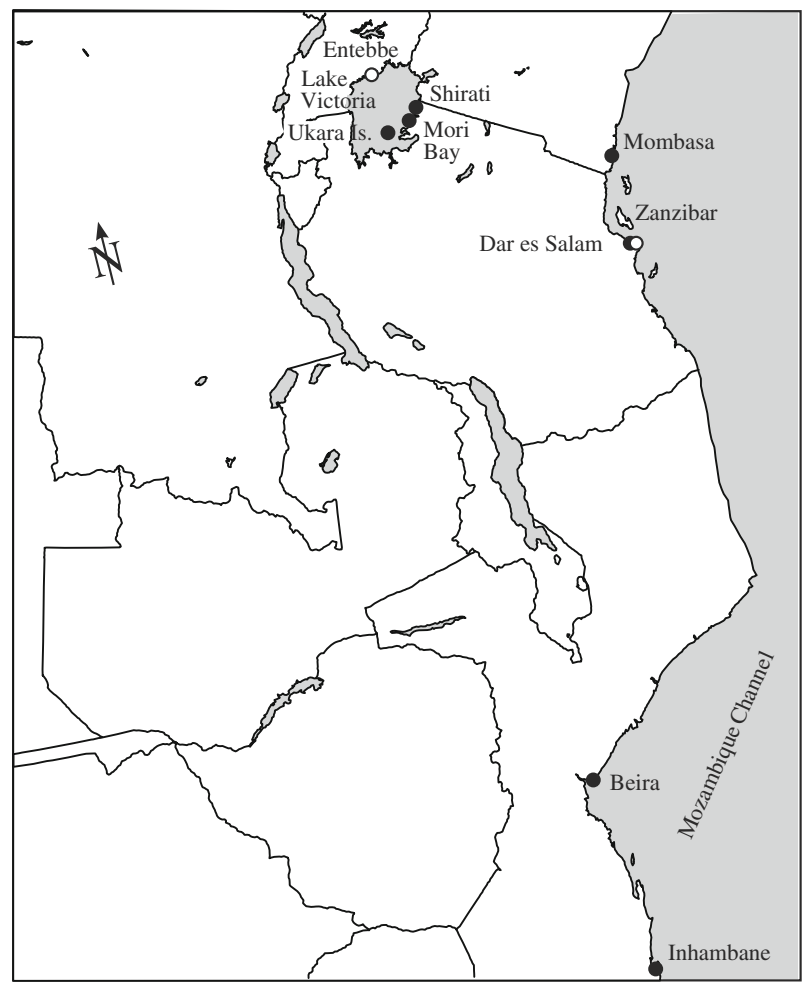

Figure 3: Map of East Africa showing the locations of aerological soundings made by BERSON (full dots) as well as existing meteorological stations (open circles). Sea-level pressure from the latter two stations constitutes the main source of information assimilated into $20 \mathrm{CR}$ for the region shown.

other studies. ASSMANN privately funded the preparations of the expedition, but all attempts to obtain funding for the expedition were unsuccessful, the last attempt on the day the expedition started. ASSMANN encouraged BERSON to depart anyway, while he continued trying to obtain funding. Finally, ASSMANN managed to secure funding from several private contributors.

Together with HERMANN ELIAS, ARTHUR BERSON performed aerological field work on Lake Victoria, in Dar es Salaam, and later in Mozambique and the Mozambique Channel (see Fig. 3). Even simultaneous ascents (Mombasa, Lake Victoria) were performed. BERSON and ELIAS used pilot balloons, kites (see Fig. 4), and registering balloons. The aim was to use ships as platforms which were considered suitable both for kites and balloons. However, only a slow ship could be found and the rubber balloons were of low quality. On sea, a steam ship, the light cruiser S.M.S. Bussard of the German Imperial Navy, was used. In total 25 registering balloon ascents, 65 kite ascents, and 84 pilot balloon ascents were performed.

One of the main scientific aims of BERSON's expedition was to analyze the East African monsoon circulation. A schematic figure of the circulation is given in the paper, focusing on the interaction of seasonally and diurnally varying circulation systems (including the sea breeze of Lake Victoria). The local circulation systems heavily
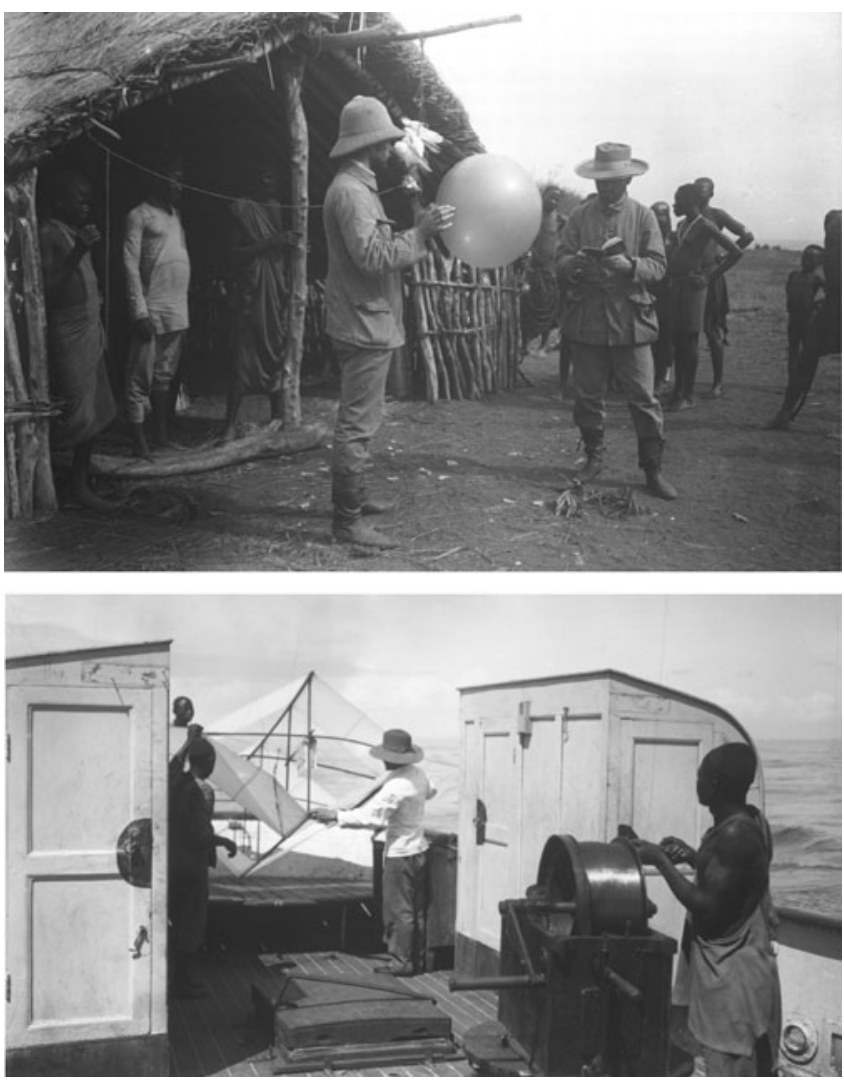

Figure 4: Pilot balloon ascent at Mori Bay, Lake Victoria (top), preparations for a kite ascent onboard the vessel "Rovuma" in the Indian Ocean (bottom). Both photos are from the archive at Lindenberg and were provided by H. STEINHAGEN.

modulate the large-scale trade wind system in the lowest $4 \mathrm{~km}$ of the atmosphere. Other results include the observation that the tropical tropopause is much higher and colder than that at midlatitudes. Also, BERSON and ELIAS observed westerly winds in the lower tropical stratosphere.

The results of the expedition were published in a report by BERSON (1910) in the series "Ergebnisse der Arbeiten des Königlich Preußischen Aeronautischen Observatoriums bei Lindenberg" (edited by ASSMANN). The paper in the Meteorologische Zeitschrift by SÜRING, translated and edited in this volume (SÜRING, 1910), is a summary of that report.

\section{Present day view of BERSON's result}

\subsection{The tropical tropopause}

From a present day perspective, BERSON's expedition was a milestone in the history of meteorology. But it was not so much the study of the monsoon flow, which is hardly remembered nowadays, that had a major impact (for a more recent overview of the East African monsoon see NICHOLSON, 1996). However, the high altitude and low temperature of the tropical tropopause in contrast to the mid-latitudes and the discovery of westerly winds 


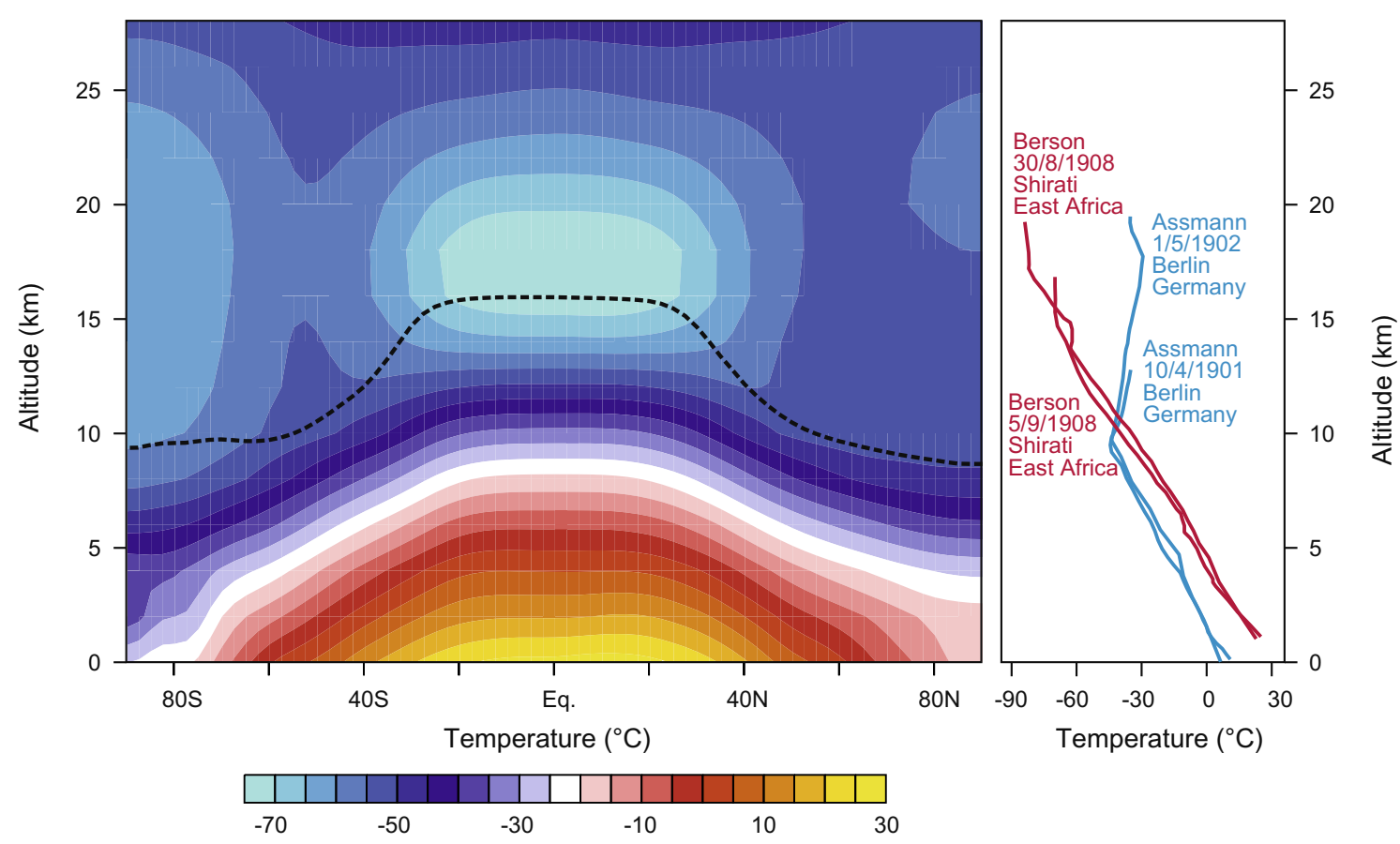

Figure 5: (left) Altitude-latitude cross-section of temperature from the NCEP/NCAR reanalysis data set (KALNAY et al., 1996), 1981-2010. The dashed line indicates the tropopause altitude as given in the NCEP/NCAR reanalysis. (right) Temperature profiles from balloon ascents made by ASSMANN in Berlin in 1901 and 1902 (blue) and by BERSON in East Africa in 1908 (red). The profile from 10 April 1901 may have been the first profile to show the tropopause. ASSMANN was clearly aware of the relevance of this finding, but pointed out that the reliability of the measurements needs to be established more firmly (ASSMANN in ASSMANN and BERSON, 1902). ${ }^{1}$

in the tropical lower stratosphere were lasting contributions to science.

When BERSON started his expedition, the discovery of the tropopause was still recent and it was unknown whether or not an inversion or isothermal layer would also be found in the tropics, and if so, at which altitude. Nowadays, the difference in the vertical thermal structure of the troposphere and stratosphere between tropical regions and high latitudes is common knowledge (see Fig. 5, left). The tropical tropopause is, on average almost twice as high as that over mid-to-high latitudes and considerably colder. This text book knowledge goes back to BERSON's expedition and his comparison of the results with the previous observations in Berlin (see Fig. 5, right). BERSON speculated that their measurements of tropical lower stratospheric temperature $\left(-84.3{ }^{\circ} \mathrm{C}\right)$ were the lowest temperatures measured in the Earth's atmosphere thus far. The low tropical tropopause temperatures are the reason for the dryness of the stratosphere. Because of its important role in radiative processes, cirrus cloud formation, and stratospheric composition, the tropical tropopause region has become a very active research area in the past years (FUEGLISTALER et al., 2009). One lesson learned from the recent research is that the tropical tropopause is not a clearly defined surface but a transition layer in manifold ways.

\footnotetext{
${ }^{1}$ Following are five German quotes from ASSMANN and BERSON's publication (ASSMANN and BERSON, 1902):

"Schon bei dem ersten Blicke bemerkt man, dass [die Messkurve] [...] in den höchsten erreichten Schichten ein ganz ungewöhnliches Bild darbietet. [...] [Auf $8700 \mathrm{~m}$ ü.M.] scheint aufs neue ein intensives Temperatur-Gefälle einzusetzen [...], aber es bricht kurz ab, um wie die Kurve zeigt und die Tabelle angiebt, nach einer kurzen Isothermie in eine schnelle Temperaturzunahme überzugehen, die, bei $10000 \mathrm{~m}$ beginnend, trotz fortgesetzten Steigens des Ballons bis zur Höhe von $12850 \mathrm{~m}$ andauert [...]. Leider drang der Ballon nicht weiter vor, um über die obere Grenze dieser Umkehrschicht Aufschluss zu liefern."

"Man wird also [...] hieraus den interessanten Schluss ziehen, dass in einer Höhe von 10-13000 m oberhalb einer Cirrostratusdecke eine intensive TemperaturUmkehrung vorhanden gewesen ist, bei welcher die Temperatur von $-44^{\circ}$ auf $-35^{\circ}$ gestiegen ist."

"Die, wie ich glaube aussprechen zu dürfen, durchaus glaubwürdige und korrekte Registrirung einer beträchtlichen, in solcher Höhe wohl noch niemals beobachteten Temperatur-Umkehrung im Betrage von $9^{\circ}$ und einer vertikalen Erstreckung von wahrscheinlich 6-7 km, ist natürlich das für die Dynamik der höheren Luftschichten wichtigste, aber auch rätselhafteste Ergebnis."

"Die höchste vom Ballon erreichte Schicht zeigte schon eine deutliche Annäherung an Isothermie, die vermuthlich bei 15 km Höhe in eine Abnahme übergegangen sein würde. [...] Selbstverständlich lässt sich die Möglichkeit einer noch weiter aufwärts reichenden Temperatur-Zunahme durchaus nicht in Abrede stellen; die hier einsetzende Strahlungswirkung und das Ende des Aufsteigens des Ballons begrenzt leider das Experiment allzu früh."

"In Anbetracht der auch so schon wahrscheinlich grossen Mächtigkeit der Umkehrschicht ist es wohl nicht unstatthaft, den gefundenen Strom wärmerer Luft als einen Zweig der grossen Luftcirkulation zwischen dem Aequator und den höheren Breiten anzusehen, der die über den tropischen Meeren unter steter Kondensation aufgestiegenen und deshalb verhältnismässig hoch temperirten Luftmassen auf abwärts geneigter Bahn polwärts führt und infolge der hierbei eintretenden Verengerung des Strombettes zur Bildung von Wirbeln in den tieferen Schichten Veranlassung giebt."

"Dieser Versuch lehrt aber ferner, wie nothwendig es ist, den bei Ballon-sonde-Aufstiegen gewonnenen Registrirungen eine Zuverlässigkeit zu geben, die alle Zweifel ausschliesst. So lange dieses Ziel nicht erreicht ist, wird man manches ähnliche Resultat ungenutzt lassen müssen, da man nicht zu entscheiden vermag, ob thatsächliche Verhältnisse oder Fälschungen durch die Sonnenstrahlung vorgelegen haben."
} 

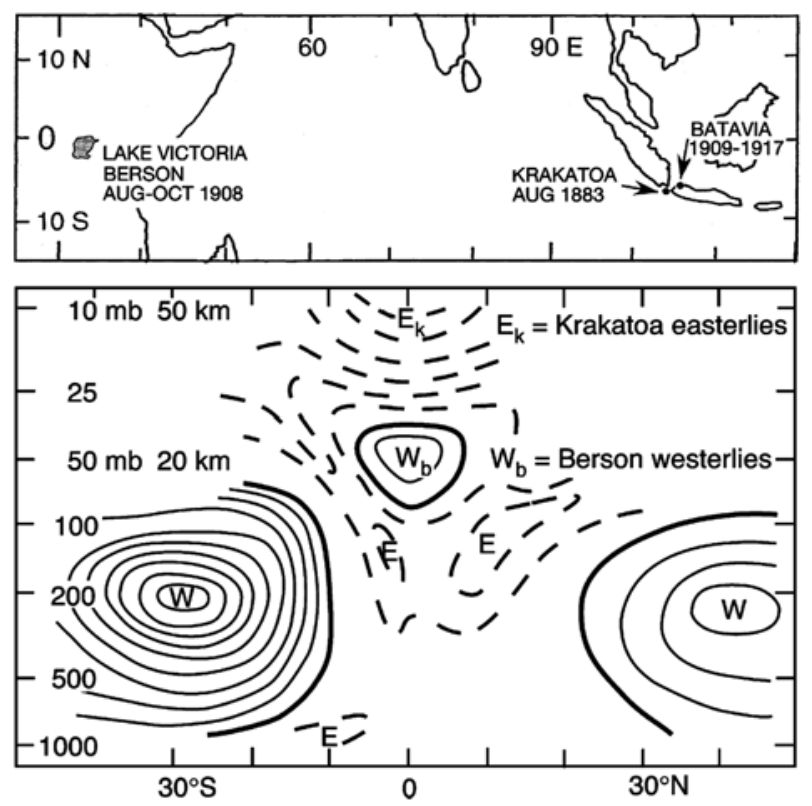

Figure 6: Conceptual view of the zonal circulation as it was envisaged until around 1960 (reprinted from HASTENRATH, 2007, with permission from Elsevier).

\subsection{The BERSON westerlies}

A minor note of BERSON's report and SÜRING's paper received a lot of attention in the following years and decades. BERSON reported that they observed westerly winds in the equatorial lower stratosphere. This finding was in apparent conflict with the notion that easterly winds prevail in the equatorial regions at high altitude, which had emerged from the observation of the ash cloud after the Krakatoa eruption (SYMONS 1888, see HAMILTON, 2012 for details). SÜRING (1910) noted that VAN BEMMELEN found westerlies as well in the soundings performed in Batavia. In 1914 HANN and SÜRING (cited from HAMILTON, 2012) reported that after the eruption of Semaru $(3,780 \mathrm{~m})$ on Java on 15 November 1911 , a cloud of ash rose to $19-24 \mathrm{~km}$ where it was deformed by westerlies (see HAMILTON, 2012). Easterlies and westerlies therefore needed to be reconciled. For a long time, the BERSON westerlies were believed to occupy a small cross-section in the lowermost stratosphere, surrounded by easterlies (see Fig. 6, from HASTENRATH, 2007). This view was put forth in text books until the early 1960s. The problem was only resolved when the Quasi-Biennial Oscillation (QBO) was finally discovered around 1960 by REED et al. (1961) and VERYARD and EBDON (1961) (see also LABITZKE and VAN LOON, 1999; BALDWIN et al., 2001; HAMILTON, 2012).

Today the QBO is considered important for understanding interannual variability in atmospheric dynamics and ozone (BALDWIN et al., 2001) and the effects of solar forcing on the polar stratosphere (e.g., LABITZKE et al., 2006). It even may affect midlatitude weather (BALDWIN et al., 2001). Knowing the phase of the QBO back in time

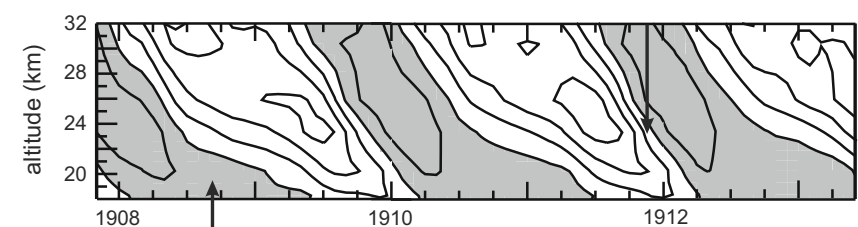

Figure 7: Monthly reconstructions of equatorial zonal mean zonal winds from 1908 to 1913 (BRÖNNIMANN et al., 2007). Westerly winds are shown in grey, easterlies in white, contour lines are $10 \mathrm{~m} / \mathrm{s}$ apart. Arrows indicate the observations of westerly winds by BERSON (left) and after the Semaru eruption (right), respectively.

would therefore be useful. A cycle-by-cycle reconstruction of the QBO back to 1908 was attempted by BRÖNNIMANN et al. (2007) based, among other sources, on VAN BEMMELEN's data that were published in summary form in EBDON (1963). Figure 7 shows the period 1908 to 1913 from this reconstruction. The reconstruction fits well with BERSON's observations, but somewhat less well with the Semaru ash cloud, for which the reconstruction suggests mainly easterlies. The results are not inconsistent as only a slight delay in the phase change in the reconstruction or an underestimation of the cloud altitude by HANN and SÜRING might account for the differences. This shows how difficult it is to estimate the QBO phase based on sparse observations. Further historical observations might help to reconcile the different information. Although from today's perspective, the QBO appears as a quite regular phenomenon, it was not possible to detect it before more frequent observations from the equatorial stratosphere became available with the International Geophysical Year in 1957.

\section{Re-evaluating BERSON's data}

In the context of the European project ERA-CLIM, we have digitized large amounts of historical upper-air data, including those from the BERSON expedition (as well as most other aerological observations mentioned). In the following we present some of these data.

The data from the BERSON expedition encompass the pilot balloon and kite observations from October 1908 taken on-board the S.M.S. Bussard which was cruising along the Indian Ocean coasts of Kenya, Tanzania and passing the island of Zanzibar through the Channel of Mozambique as well as 12 upper-air records obtained at fixed land locations and on-board the steamer "Husseini" on Lake Victoria. Of these 12 series, 6 contain pilot balloon wind data recorded at Beira (Mozambique), Dar es Salaam (Tanzania), Mombasa (Kenya), and at three different locations at or on Lake Victoria (see Fig. 3). Kites were launched at five locations: Dar es Salaam, Inhambane (Mozambique), Mombasa, and at two locations on Lake Victoria. Finally, one record contains data from registering balloon ascents done at a location at Lake Victoria (see Fig. 3). The first records start at Lake Victoria 

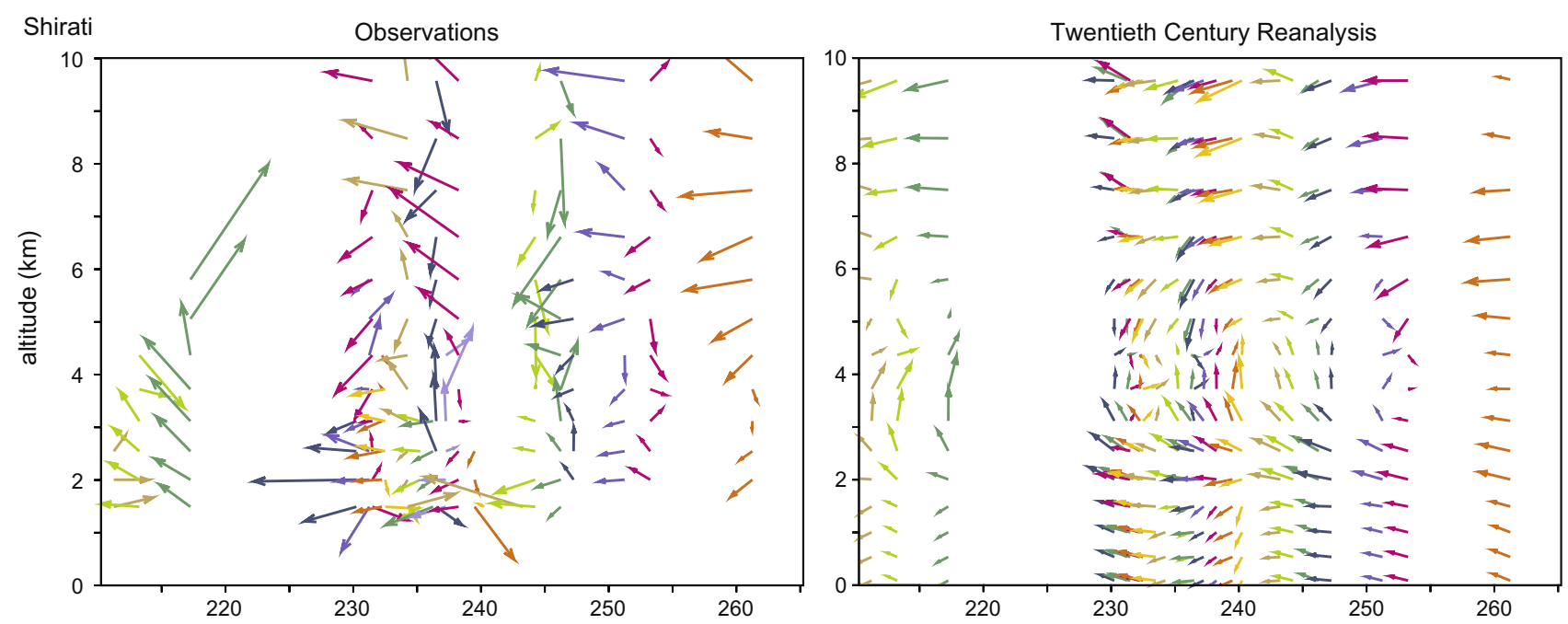

Dar es Salam
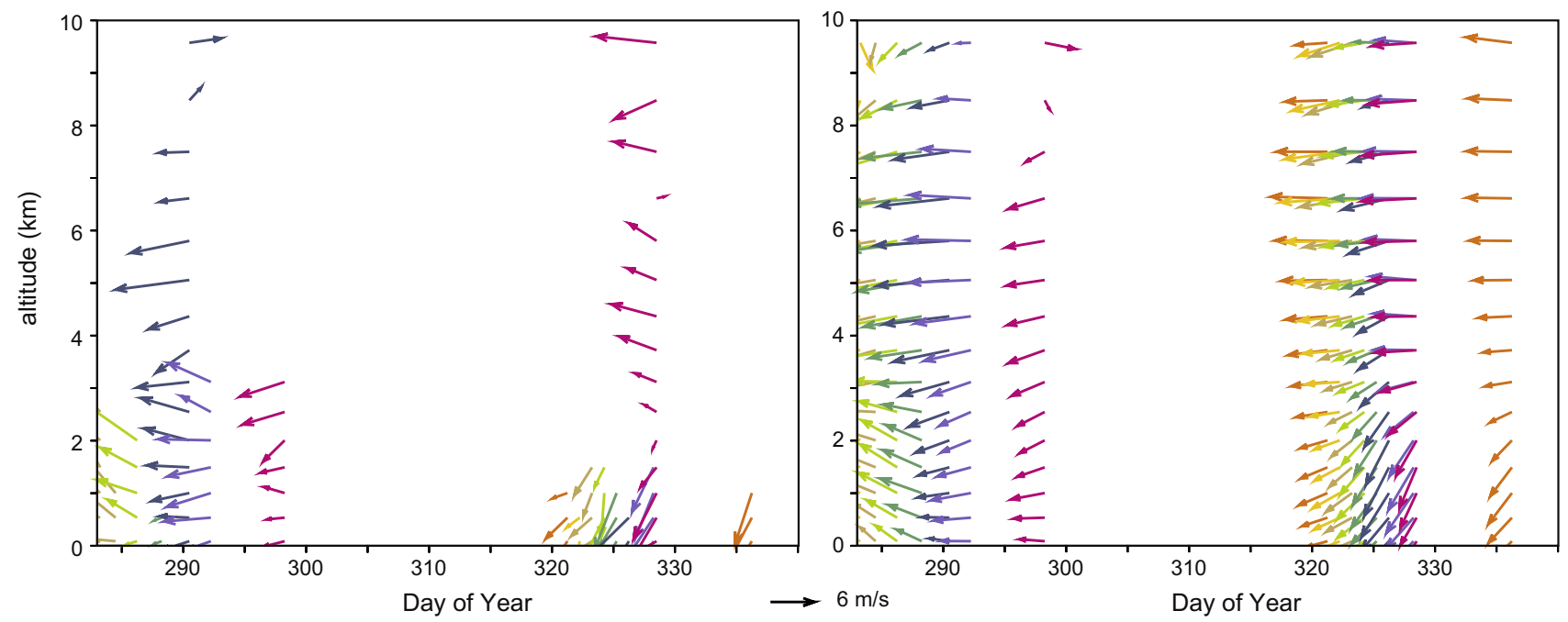

Figure 8: Wind vectors from BERSON's observations (left) and corresponding data from 20CR (right) from Shirati in August and September 1908 (top) and from Dar es Salaam from October to December 1908. The observations were interpolated to the pressure levels of $20 \mathrm{CR}$.

in July 1908. During September and October 1908, simultaneous observations were performed at Lake Victoria and in Mombasa. The measurements in Mozambique were made later on from October to December 1908.

Determining the monsoon circulation was not only a problem to BERSON, but even current reanalysis data sets do not agree in the monsoon regions. For the mid-twentieth century, biases relative to observations that are as large as the mean were found (STICKLER and BRÖNNIMANN, 2011). It is therefore important to compare the new historical reanalysis data sets with observations from the past, which however have been unavailable until recently. A large amount of historical upper-air data was recently compiled by STICKLER et al. (2010). The newly digitized data will add to this collection.

In this section we compare BERSON's data with corresponding data extracted from the "Twentieth Century Reanalysis" (20CR, COMPO et al., 2011). 20CR is a global, 3-dimensional atmospheric data set that is based on the assimilation of only surface and sea-level pressure, with monthly sea-surface temperatures and sea ice used as boundary conditions. 20CR provides data back to 1871, but first validations have shown that its quality is worse in the tropics than at midlatitudes (COMPO et al., 2011; BRÖNNIMANN et al., 2011; BRÖNNIMANN and COMPO, 2012). This might be due to the fact that air pressure does not constrain atmospheric circulation well enough in the tropics due to the vanishing Coriolis acceleration. It might also simply be due to the fact that almost no pressure information was available for the tropics. In 1908, air pressure was only available from three stations in the whole of Africa (in addition to occasional ship data), two of which were in East Africa (Entebbe, Dar es Salaam, see Fig. 3). It is interesting to compare the atmospheric circulation in $20 \mathrm{CR}$, constrained by such little information, with independent historical upper-air information.

For the comparison we used the ensemble mean of 20CR from the closest synoptic time (20CR is available for $0,6,12$, and $18 \mathrm{UTC}$ ), linearly interpolated to the 
station coordinates. Here we only show the results for the wind profiles obtained with pilot balloons at Shirati and Dar es Salaam (in addition, two temperature profiles from Shirati are shown in Fig. 5). The observations were interpolated to the pressure levels from 20CR using geopotential height from 20CR. In rare cases, more than one profile was available for the same synoptic time; in this case we averaged the profiles. Profiles that did not reach $500 \mathrm{~m}$ above ground were ignored, Because of the spatial interpolation of 20CR and because we use the ensemble mean, we expect 20CR to exhibit rather smooth profiles with little variability.

The results (Fig. 8) show clear differences between the inland site Shirati at the shore of Lake Victoria and the coastal site Dar es Salaam. In Dar es Salaam, the soundings were performed during the north-easterly monsoon season. Easterly winds dominate above around $2 \mathrm{~km}$. In the lowest layers, a transition from southerly (during the first profiles) to northerly wind components is found. 20CR and observations agree well with respect to the average circulation, but also with respect to day-today variability. At Shirati, the picture is more complex both in the observations and in 20CR. Here the profiles were obtained during the southeast monsoon season according to SÜRING (1910). The observations appear to be much more noisy, which however may also be due to diurnal wind changes (which might be more local and thus less well captured by 20CR) on top of seasonal and intraseasonal changes. Some of the features, such as the frequent southerly winds at around $4 \mathrm{~km}$ and increasing easterly wind speeds above or also some of the intraseasonal features appear in both data sets. However, the general agreement is clearly worse.

Note that only two station series of air pressure were available and thus provided most of the information on day-to-day variability for $20 \mathrm{CR}$. Considering this fact, the agreement between 20CR and BERSON's data is promising. However, differences arise with respect to the complex circulation near the shore of Lake Victoria. This shows that including BERSON's data in future reanalysis approaches might provide much more detailed information.

\section{Conclusion}

ARTHUR BERSON's aerological expedition to East Africa in 1908 fell into a period of exploration of tropical meteorology and of expansion of the new tool of aerological observations to other regions, promoted with enthusiasm by the International Aeronautical Association. From a present day perspective, BERSON's expedition was a milestone in the history of meteorology. But it was not so much the study of the monsoon flow (the original intention) that makes the work relevant today, but the observation of the high and cold tropical tropopause and of westerly winds in the tropical lower stratosphere. The westerly winds were in conflict with the supposed easterly winds that were known since the Krakatoa eruption - a puzzle that was only resolved five decades later with the discovery of the Quasi-Biennial Oscillation (QBO).

We have digitized BERSON's aerological data and compare wind profiles with the "Twentieth Century Reanalysis". A good agreement is found near the coast (which is surprising considering the very sparse input into 20CR), but the agreement deteriorates further inland. This shows that BERSON's observations are still valuable today as input to current reanalysis systems or for validation in order to improve the quality and to arrive at a global reconstruction of the daily weather back into the early $20^{\text {th }}$ or even $19^{\text {th }}$ century.

\section{Acknowledgements}

The work was funded by the EC FP7 project ERA-CLIM and by the Swiss National Science Foundation project EVALUATE. 20CR data were provided by courtesy of the NOAA/OAR/ESRL PSD, Boulder, Colorado, USA (http://www.esrl.noaa.gov/psd/). Support for the Twentieth Century Reanalysis Project dataset is provided by the U.S. Department of Energy, Office of Science Innovative and Novel Computational Impact on Theory and Experiment (DOE INCITE) program, and Office of Biological and Environmental Research (BER), and by the National Oceanic and Atmospheric Administration Climate Program Office. We would like to thank Hans Steinhagen for providing the photographs.

\section{References}

ASSMANN, R., 1902: Über die Existenz eines wärmeren Luftstromes in der Höhe von 10 bis $15 \mathrm{~km}$. - Sitzber. Königl. Preuss. Akad. Wiss. Berlin 24, 495-504.

ASSMANN, R., A. BERSON (Eds.), 1899: Wissenschaftliche Luftfahrten. Erster Band. Geschichte und Beobachtungsmaterial. Vieweg und Sohn (Braunschweig).

Assmann, R., A. BERSON (Eds.), 1900a: Wissenschaftliche Luftfahrten. Zweiter Band. Beschreibung und Ergebnisse der einzelnen Fahrten. Vieweg und Sohn (Braunschweig).

ASSMANN, R., A. BERSON (Eds.), 1900b: Wissenschaftliche Luftfahrten. Dritter Band. Zusammenfassung und Hauptergebnisse. Vieweg und Sohn (Braunschweig).

AssmanN, R., A. Berson, 1902: Ergebnisse der Arbeiten am Aëronautischen Observatorium in den Jahren 1900 und 1901 (Ed. VON BEZOLD). - Asher \& Co. (Berlin).

BALDWIN, M. P., L. J. GRAY, T. J. DUNKERTON, K. Hamilton, P. H. Haynes, W. J. RANDEL, J. R. Holton, M. J. Alexander, I. Hirota, T. Horinouchi, D. B. A. Jones, J. S. Kinnersley, C. Marquardt, K. Sato, M. TAKAHASHI, 2001: The Quasi-biennial oscillation. - Rev. Geophys. 39, 179-229.

BERSON, A., 1910: Bericht über die aerologische Expedition des königlichen aeronautischen Observatoriums nach 
Ostafrika im Jahre 1908. - Königlich Preußischen Aeronautischen Observatoriums bei Lindenberg (ed. ASSMANN).

BERNHARDT, K., 2000: Zur Erforschung der Atmosphäre mit dem Freiballon - Die Berliner wissenschaftlichen Luftfahrten. - Dahlemer Archivgespräche 6/2000, 52-82.

BRÖNNIMANN, S., G. P. COMPO, 2012: Ozone highs and associated flow features in the first half of the twentieth century in different data sets. - Meteorol. Z. 21, 49-59.

Brönnimann, S., J. L. Annis, C. Vogler, P. D. Jones, 2007: Reconstructing the Quasi-Biennial Oscillation back to the early 1900s. - Geophys. Res. Lett. 34, L22805. doi:10.1029/2007GL031354.

BRÖNNIMANN, S., G. P. COMPO, R. SPADIN, R. Allan, W. ADAM, 2011: Early ship-based upper-air data and comparison with the Twentieth Century Reanalysis. - Clim. Past 7, 265-276.

Compo, G. P., J. S. Whitaker, P. D. SARdeshmukH, N. Matsui, R. J. Allan, X. Yin, B. E. Gleason, R. S. Vose, G. Rutledge, P. Bessemoulin, S. BRÖNNIMANN, M. Brunet, R. I. Crouthamel, A. N. Grant, P. Y. Groisman, P. D. Jones, M. KruK, A. C. Kruger, G. J. Marshall, M. MaUgeri, H. Y. MOK, Ø. Nordli, T. F. Ross, R. M. Trigo, X. L. Wang, S. D. Woodruff, S. J. WORLEY, 2011: The Twentieth Century Reanalysis Project. - Q. J. Roy. Meteor. Soc. 137, 1-28.

DE ORY, F., M. PALOMARES, 2005: The observation of the atmosphere in Tenerife Island during the last centuries and the mountain observatory in Izaña. - Algorismus 52, 129-142.

EMEIS, S., 2008: History of the Meteorologische Zeitschrift. - Meteorol. Z. 17, 685-693.

EMEIS, S., 2012: Assmann's development of aspiration psychrometers. - Meteorol. Z. 21, 431-435.

EBDON, R. A., 1963: The tropical stratospheric wind fluctuation: Evidence of its permanency from earlier data. - Weather 18, 2-7.

FERREL, W., 1856: An essay on the winds and the currents of the Oceans. - Nashville Journal of Medicine and Surgery 11, Nos. 4 and 5 (http://www.aos.princeton.edu/WWWPUBLIC/gkv/history/ferrel-nashville56.pdf, accessed 19 Nov. 2012).

Fueglistaler, S., A. E. Dessler, T. Dunkerton, I. Folkins, Q. FU, P. W. MOTE, 2009: Tropical Tropopause Layer. - Rev. Geophys. 47, RG1004, doi:10.1029/ 2008RG000267.

GRAmelsberger, G., 2009: Conceiving Meteorology as the exact science of the atmosphere: Vilhelm Bjerknes's paper of 1904 as a milestone. - Meteorol. Z. 18, 669-673.

HadLeY, G., 1735: Concerning the Cause of the General Trade-Winds. - Phil. Trans. 39, 58-62.

Halley, E., 1686: An Historical Account of the Trade Winds, and Monsoons, Observable in the Seas between and Near the Tropicks, with an Attempt to Assign the Phisical Cause of the Said Winds. - Phil. Trans. 16, 153168.

HAMILTON, K., 2012: Sereno Bishop, Rollo Russell, Bishop's Ring and the Discovery of the "Krakatoa Easterlies". - Atmosphere-Ocean 50, 169-175.
HANN, J., 1887: Atlas der Meteorologie. - Justus Perthes, Gotha.

HANN, J., R. SÜRING (ED.), 1915: Lehrbuch der Meteorologie. $3^{\text {rd }}$ Edition. - Tauchnitz (Leipzig).

HASTENRATH, S., 2007: Equatorial zonal circulations: Historical perspectives. - Dynamics of Atmospheres and Oceans 43, 16-24.

HILDEBRANDT, A., 1907: Die Luftschiffahrt nach ihrer geschichtlichen und gegenwärtigen Entwicklung. R. Oldenbourg, $426 \mathrm{pp}$.

Kalnay, E., M. Kanamitsu, R. Kistler, W. Collins, D. DeAVEN, L. GANdin, M. IREDEll, S. SAHA, G. White, J. WoOllen, Y. ZHU, A. LeETMAA, R. ReYNOLdS, M. CHElliah, W. EBISUZAKI, W. HigGINS, J. JANOWIAK, K. C. Mo, C. Ropelewski, J. WANG, R. Jenne, D. Joseph, 1996: The NCEP/NCAR 40-Year Reanalysis Project. - B. Am. Meteorol. Soc. 77, 437-471.

LABITZKE, K., H. V. LoON, 1999: The Stratosphere: Phenomena, History and Relevance. - Springer, 179 pp.

LABITZKE, K., M. KUNZE, S. BRÖNNIMANN, 2006: Sunspots, the QBO and the stratosphere in the North Polar region 20 years later. - Meteorol. Z. 15, 355-363.

NiCHOLSON, S. E., 1996: A review of climate dynamics and climate variability in eastern Africa. - In: JOHNSON T.C., E. ODADA (Eds.) The limnology, climatology and paleoclimatology of the East African lakes, Gordon and Breach, Amsterdam, p. 25-56.

PRINCE ALBERT of MONACO, 1907: Meteorological Researches in the High Atmosphere. - Scottish Geographical Magazine 23, 113-122.

Reed, R. G., W. J. CAmpbell, L. A. Rasmussen, D. G. ROGERS, 1961: Evidence of downward-propagating annual wind reversal in the equatorial stratosphere. - J. Geophys. Res. 66, 813-818.

RIEHL, H., 1954: Tropical meteorology. - McGraw-Hill Books, New York, Toronto, London, 392 pp.

RoTCH, A. L., 1902: The circulation of the atmosphere in the tropical and equatorial regions. - Mon. Wea. Rev. 30, 181183.

SHAW, W. N., 1905: The Pulse of the Atmospheric Circulation. - Nature 73, 175-177.

SteinhaGeN, H., 2009a: Zum 150. Geburtstag von Hugo Hergesell. - dmg-Mitteilungen 01/2009, 7-10.

STEINHAGEN, H., 2009b: Zum 150. Geburtstag von Arthur Berson. - dmg-Mitteilungen 04/2009, 11-13.

Stickler, A., A. N. Grant, T. Ewen, T. F. Ross, R. S. Vose, J. Comeaux, P. Bessemoulin, K. Jylhä, W. K. Adam, P. Jeannet, A. Nagurny, A. M. Sterin, R. Allan, G. P. COMPO, T. GRIESSER, S. BRÖNNIMANN, 2010: The Comprehensive Historical Upper Air Network (CHUAN). - B. Am. Meteorol. Soc. 91, 741-751.

STICKLER, A., S. BRÖNNIMANN, 2011: Significant bias of the NCEP/NCAR and Twentieth Century reanalyses relative to pilot balloon observations over the West African monsoon region(1940-57). - Q. J. Roy. Meteorol. Soc. 137, 1400-1416.

SYMONS, G. J., 1888: The Eruption of Krakatoa, and subsequent phenomena. Report of the Krakatoa Committee of the Royal Society. - Trübner \& Company, 494 pp. 
SÜRING, R., 1910: A. Berson's Bericht über die aerologische Expedition des königlichen aeronautischen $\mathrm{Ob}$ servatoriums nach Ostafrika im Jahre 1908 (Report by A. Berson about the aerological expedition of the Royal Aeronautic Observatory to Eastern Africa in 1908). - Meteorol. Z. 27, 536-542. (translated and edited by VOLKEN E. and S. BRÖNNIMANN - Meteorol. Z. 22 (2013), XXX-XXX-)

SÜRING, R., 1943: Nachruf auf Arthur Berson. - Meteorol. Z. 60, 26-28.
TEISSERENC DE BORT, L.-P., 1902: Variations de la temperature de l'air libre dans la zone comprise $8 \mathrm{~km}$ et $13 \mathrm{~km}$ d'altitude. - C. R. Hebd. Seances Acad. Sci. 24, 987-989.

VAN BEMMELEN, W., 1911: Die Windverhältnisse in den oberen Luftschichten nach Ballonvisierungen in Batavia. Koninklijk Magnetisch en Meteorologisch Observatorium te Batavia. Verhandelingen No. 1.

VERYARD, R. G., R. A. EBDON, 1961: Fluctuations in tropical stratospheric winds. - The Meteorological magazine 90, 125-143. 